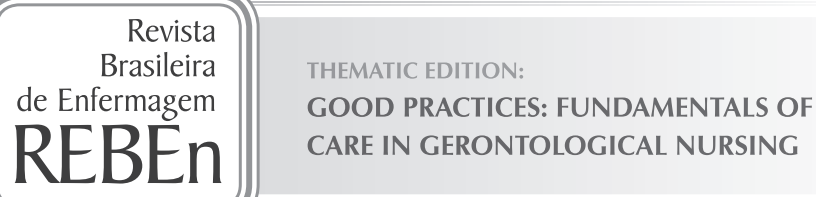

\title{
Association between filial responsibility when caring for parents and the caregivers overload
}

\author{
Associação entre responsabilidade filial no cuidado aos pais e sobrecarga dos cuidadores \\ Asociación entre responsabilidad en el cuidado de los padres y sobrecarga de los cuidadores
}

\section{Marinês Aires', Duane Mocellin', Fernanda Laís Fengler', Idiane Rosset', Naiana Oliveira dos Santos', Diani de Oliveira Machado', Carolina Baltar Day', Lisiane Manganelli Girardi Paskulin'}

\begin{abstract}
' Universidade Federal do Rio Grande do Sul, School of Nursing, Postgraduate Program in Nursing. Rio Grande, Rio Grande do Sul, Brazil.
\end{abstract}

\section{How to cite this article:}

Aires M, Mocellin D, Fengler FL, Rosset I, Santos NO, Machado DO, et al. Association between filial responsibility when caring for parents and the caregivers overload. Rev Bras Enferm [Internet]. 2017;70(4):767-74. [Thematic Edition “Good Practices: Fundamentals of care in Gerontological Nursing"] DOI: http://dx.doi.org/10.1590/0034-7167-2017-0133

Submission: 02-15-2017 Approval: 04-03-2017

\begin{abstract}
Objective: To analyze the association between filial responsibility and the overload of the children when caring for their older parents. Method: Cross-sectional study with 100 caregiver children of older adults. Filial liability was assessed by the attitudes of the responsible child (scale of expectation and filial duty) and by care behaviors (assistance in activities of daily living, emotional and financial support, and keeping company). The overload was assessed by the Caregiver Burden Inventory. To assess the associations, the correlation coefficients of Pearson and Spearman, Kruskal-Wallis Test, and Mann-Whitney were employed. Variables that presented $p$-value $<0.20$ in the bivariate analysis were inserted in a multivariate linear regression model. Results: The factors associated with overload were: formal employment $(p=0.002)$, feelings regarding family life $(p<0.001)$, financial support $(p=0.027)$, and assistance with Activities of Daily Living (ADLs) $(p<0.001)$. Conclusion: Children who were more involved with the ADLs and provided financial support showed higher levels of overload.
\end{abstract}

Descriptors: Caregivers; Older Adults; Family Relationships; Nursing; Geriatric Nursing.

\section{RESUMO}

Objetivo: Analisar a associação entre a responsabilidade filial e a sobrecarga dos filhos cuidadores de pessoas idosas. Método: Estudo transversal com 100 filhos cuidadores de pessoas idosas. A responsabilidade filial foi avaliada pelas atitudes de responsabilidade filial (escala de expectativa e dever filial) e pelos comportamentos de cuidar (auxílio nas atividades de vida diária, apoio emocional, financeiro e companhia). A sobrecarga foi avaliada pelo Inventário de Sobrecarga do Cuidador. Para avaliar as associações utilizaram-se os coeficientes de correlação de Pearson e Spearman, Teste de Kruskal-Wallis e Mannwhitney. Variáveis que apresentaram valor de $p<0,20$ na análise bivariada foram inseridas em um modelo multivariado de regressão linear. Resultados: Os fatores associados com a sobrecarga foram: emprego formal $(p=0,002)$, sentimentos na vida familiar ( $p<0,001)$, apoio financeiro $(p=0,027)$ e ajuda nas Atividades da Vida Diária (AVDs) $(p<0,001)$. Conclusão: Os filhos que mais auxiliavam nas AVDs e prestavam apoio financeiro apresentaram maiores níveis de sobrecarga.

Descritores: Cuidadores; Idosos; Relações Familiares; Enfermagem; Enfermagem Geriátrica.

\section{RESUMEN}

Objetivo: Analizar la asociación entre responsabilidad filial y sobrecarga en hijos cuidadores de personas ancianas. Método: Estudio transversal con 100 hijos cuidadores de personas ancianas. La responsabilidad filial fue evaluada por las actitudes de responsabilidad filial (escala de expectativa y deber filia) y por los comportamientos de cuidar (ayuda en actividades diarias, apoyo emocional, económico y compañía). La sobrecarga se evaluó según Inventario de Sobrecarga del Cuidador. Para evaluar las asociaciones se utilizaron coeficientes de correlación de Pearson y Spearman, Tests de Kruskal-Wallis y Mann-Whitney. Las variables con valores de $p<0,20$ en el análisis bivariado fueron sometidas a modelo multivariado de regresión lineal. 
Resultados: Los factores asociados con sobrecarga fueron: empleo formal $(p=0,002)$, sentimientos en vida familiar $(p<0,001)$, apoyo económico $(p=0,0027)$ y ayuda en Actividades de la Vida Diaria (AVDs) $(p<0,001)$. Conclusión: Los hijos que más colaboraban en AVDs y prestaban apoyo económico presentaron mayores niveles de sobrecarga.

Descriptores: Cuidadores; Anciano; Relaciones Familiares; Enfermería; Enfermería Geriátrica.

\section{CORRESPONDING AUTHOR Marinês Aires_Email: marynesayres@yahoo.com.br}

\section{INTRODUCTION}

Filial responsibility is defined as a social or cultural norm regarding the behavior of children to the process of care with older parents and can be considered as an individual attitude or belief (related to the obligation) that potentially motivates care behaviors ${ }^{(1-3)}$. Filial responsibility attitudes and the behaviors of children of caring for and supporting their parents in this process can be used to measure filial responsibility ${ }^{(3)}$.

The attitude in this context is understood as a personal assessment that involves a transitory or permanent opinion when assessing positively or negatively a category of people or situations ${ }^{(4)}$. The term "behavior", from the perspective of filial responsibility, is understood as an individual conduct to provide care or support older parents ${ }^{(5)}$. Thus, the attitudes of responsibility do not necessarily predict the behaviors of care, however, they involve a causal relationship with care behaviors in general, as well as exert influences on the individual behavior of the children ${ }^{(3,6)}$.

The responsibility of children in caring for parents can be a protective factor (or not) for the well-being of caregivers, and can cause overload to them ${ }^{(4)}$. Becoming a caregiver is often a condition imposed by the family nucleus or assumed due to lack of other options in the family nucleus, or outside $i^{\left({ }^{77}\right.}$. Thus, many caregivers feel compelled to take care of the older adult, considering it a moral duty or social role due to affective ties $^{(8)}$. Performing this role can generate feelings of helplessness, depression, anxiety, interpersonal conflict, reduced satisfaction with life and, therefore, an overload related to care ${ }^{(4,7,9)}$.

Many national studies highlight factors related to the overload of caregivers. Among these, stand out: those related to clinical conditions of the older adults and their functional capacity; those related to the caregiver, such as female gender, age, low educational level, and feelings of having to fulfill a costly and tense-inducing obligation; and those related to the demands of care, how to live with the older adult, the type of task undertaken, the little emotional, financial and instrumental support they receive, the accumulation of functions, and full-time care ${ }^{(8,10-14)}$.

International studies indicate factors influencing overload: the behavioral problems of the older adult, dependence, age of the caregivers, individualization of the family, daily care, inadequate social support, and financial demands $s^{(15-19)}$.

We observed that the process of caring for an older person can reflect negatively in the life of the caregiver. However, research on the effects that the attitudes of filial responsibility, caring behaviors, beliefs and experiences of stress have on the overload of the caregiver child are still limited ${ }^{(20)}$. In addition, in Brazilian culture, it is not known how the attitudes of filial responsibility and care behaviors of the children in relation to the process of caring for their older parents may have protective or compromising effects on overload. In this sense, this study aimed to analyze the association between filial responsibility and the overload of the children when caring for their older parents.

\section{METHOD}

\section{Ethical aspects}

The study was approved by the Research Ethics Committee of the Hospital de Clínicas de Porto Alegre (HCPA).

\section{Study design, location and period}

This is a cross-sectional study that involved replication of a Canadian study ${ }^{(21)}$ in Brazil. The location of this study was two Basic Health Units of the Center Health District of the city of Porto Alegre, Rio Grande do Sul, Brazil. The proportion of older adults $\geq 60$ years residing in this region is of $22.1 \%^{(22)}$. Data were collected in 2015.

\section{Population or sample; inclusion and exclusion criteria}

The non-probability sample was of 100 caregiver children of older adults. The quantitative of the sample was the same used in the original study ${ }^{(21)}$. The caregiver children were identified by family medical records, registration in programmatic actions of older adults' health, registration in the immunization sector, indication of health professionals, and active search of the research team in the units. The inclusion criteria were: being a caregiver child for at least three months and performing at least 3 hours of care weekly (whether instrumentally, helping with ADLs or IADLs, financially or emotionally).

\section{Study protocol}

For data collection, held in 2015 through household interviews, the Filial Responsibility protocol ${ }^{(2)}$ adapted for use in Brazil was used ${ }^{(9,23)}$. The protocol assesses the responsibility of children in caring for older parents through filial responsibility attitudes and care behaviors.

Filial responsibility attitudes were assessed by the Filial Expectation Scale, the Filial Duty Scale, and overload of caregivers.

The Filial Expectation Scale ${ }^{(24)}$ verifies aspects related to attitudes like living near the parents, having space for the parents to live with the children, taking care of the parents, providing financial support, and visiting the parents in old age. The results are analyzed by the continuous sum of scores, and the higher the score, the greater the filial expectation. The scale has a maximum score of 25 points. 
The Filial Piety Scale ${ }^{(25)}$ was adapted and named in the Brazilian protocol as Filial Duty Scale ${ }^{(9)}$. It has six items and assesses: availability to help parents, follow their advice, provide financial support, respect them, please them, make them happy, and keep in touch with them. The higher the score, the higher the children's duty regarding care for older parents. The scale has a maximum score of 30 points. The assessment of psychometric measures, made by Cronbach's alpha coefficient, resulted in an internal consistency to the scales: Filial Expectation $(\alpha=0.64)$, Filial Duty $(\alpha=0.65)^{(9)}$.

Care behaviors were assessed by means of instrumental, emotional, and financial support, keeping company, and visits. The instrumental support was verified based on the scales of Activities of Daily Living (ADLs) and Instrumental Activities of Daily Living (IADLs) to identify which types of care were provided by the children to their parents ${ }^{(26-27)}$, broadly used in Brazilian studies ${ }^{(28-29)}$.

Emotional support, keeping company, and visits were assessed based on the replies to the following question: How do you feel and meet the emotional support, companionship, and visit needs of your parents? - in a scale of 1 to 5 , in which 1 represents "not at all" and 5 represents "completely". In the bivariate and multivariate analysis, for emotional support, keeping company, and visits, answers 2, 3, 4 and 5 were grouped as a dichotomous variable. (Not at all = nothing. Corresponds to: I do not feel nor meet those needs). Financial support was measured on the basis of the replies (yes or no) to the question: Do you provide financial support to your father or mother?

Overload was assessed using the Caregiver Burden Inventory ${ }^{(30)}$, adapted and validated for use in caregivers of older adults in Brazil(31). The scale is composed of 24 closed questions that measure the impact of overload in caregivers, and is divided into five aspects of overload: time-dependent; personal life; physical; social; emotional. Each question received a score of 0 (strongly disagree) to 4 (completely agree), the higher the score, the greater the overload of the caregiver. The total score of the scale is 100 points.

The variables of interest included in the bivariate analysis were sex, age group, marital status, education, formal employment, living situation, care relationship, main caregiver, co-living, time of co-living, parents' health, self-perception of health, feelings, family life, filial expectation, filial duty, emotional support, keeping company and visits, financial support, and help with ADLs and IADLs. The interest of the researchers in making such associations was to understand the role of care attitudes and responsibilities in overload. In addition, the sociodemographic and care relationships variables were included considering socioeconomic and cultural aspects, being characteristics that comprise multivariate analyses in international studies on the subject.

\section{Analysis of results and statistics}

The statistical analyses were conducted using the Statistical Package for the Social Sciences, version 18.0. The variables that presented $p<0.20$ in the bivariate analyses were inserted in a linear regression multivariate model for the control of possible confounding factors. For the overload scale, the square root transformation was used to correct the asymmetries of the variable. The associations were carried out based on the Pearson Correlation, or Spearman, Kruskal-Wallise test, and Mann-whitney test.

\section{RESULTS}

\section{Characterization of the caregiver children and of the old- er parents}

We identified the predominance of caregiver daughters (74), aged between 50 and 59 years (41), with an average age of $54.04 \pm 10.17$ years, married or living with a partner (42). The average years of formal education was $13.96 \pm 4.87$ years. Most of the caregiver children (63) were the main caregiver, i.e., they assumed full-time care, and 61 were residing with their older parents for 15 years, on average.

Most of the older parents were female (78) and widows (58). Among the older adults who did not live with their caregiver children, 13 (34.2\%) lived with other people, such as hired caregivers, grandchildren, nieces, other daughters, brothers, and friends.

The average of the Filial Expectation and Filial Duty scales represented approximately 90 and $94 \%$ of the maximum value of the scales, respectively.

When assessing the care behaviors of the children, we identified, as can be seen in Table 2, that most children helped the older parents in IADLs and a large part provided emotional support.

Table 1 - Distribution of the attitudes of filial responsibility, Porto Alegre, Rio Grande do Sul, Brazil, 2017

\begin{tabular}{lcc}
\hline Scales & $\begin{array}{c}\text { Mean } \pm \text { standard } \\
\text { deviation }\end{array}$ & $\begin{array}{c}\text { Minimum and } \\
\text { maximum }\end{array}$ \\
\hline Filial Expectation* & $22.6 \pm 2.7$ & $10-25$ \\
Filial Duty* & $28.2 \pm 1.9$ & $22-30$ \\
\hline
\end{tabular}

Note: Mean \pm standard deviation and minimum and maximum values were obtained in the sample.

Table 2 - Distribution of care behaviors: Help with Instrumental Activities of Daily Living, emotional support, keeping company, help with Activities of Daily Living, and financial support, Porto Alegre, Rio Grande do Sul, Brazil, 2017

\begin{tabular}{|c|c|}
\hline Variables & $\mathrm{n}(\mathbf{1 0 0})$ \\
\hline Help with IADLst & 93 \\
\hline Emotional support * & 80 \\
\hline Keeping companyt & 71 \\
\hline Help with ADLst & 57 \\
\hline Financial support† & 52 \\
\hline Total & 100 \\
\hline
\end{tabular}


As for the aspects of the Caregiver Burden Inventory scale, distribution was unbalanced; to compare them, we used the mean value. The assessment of overload of the caregiver children showed higher overload in the time-dependent aspect and less on emotional life. The significant variables $(p \leq 20)$ in the association with overload by means of the bivariate analysis and that were included in the multivariate analysis (Table 4) showed a relationship with socioeconomic aspects, family relationships, and care behaviors. Filial responsibility attitudes and other variables of interest were not included in the model.

Table 3 - Assessment of overload of caregiver children, Porto Alegre, Rio Grande do Sul, Brazil, 2017

\begin{tabular}{lcccc}
\hline Scales & Mean \pm SD & Mn (P25-P75) & Min-Max & \% Mean/Max \\
\hline $\begin{array}{l}\text { Caregiver Burden } \\
\text { Inventory - aspects }\end{array}$ & & & & \\
$\quad$ Dependent time & $12.1 \pm 6.2$ & $14(7.3-17)$ & $0-20$ & 48.4 \\
$\quad$ Personal life & $9.1 \pm 7.0$ & $9(2.3-15.8)$ & $0-20$ & 36.4 \\
$\quad$ Physical & $6.3 \pm 6.6$ & $3.8(0-11.3)$ & $0-20$ & 31.5 \\
$\quad$ Social & $5.7 \pm 4.7$ & $5(1-9)$ & $0-19$ & 22.8 \\
$\quad$ Emotional & $3.1 \pm 4.3$ & $1(0-5)$ & $0-20$ & 12.9 \\
Total score & $36.4 \pm 22.8$ & $35(16-56)$ & $0-81$ & 30.3 \\
\hline
\end{tabular}

Note: Mean and standard deviation, median (25-75 percentiles), minimum and maximum and mean and maximum \%; SD - standard deviation; $M n-$ mean.

Table 4 - Linear Regression Multivariate Analysis with extraction by Backward to assess predictors independently associated with the Caregiver Burden Inventory scale, Porto Alegre, Rio Grande do Sul, Brazil, 2017

\begin{tabular}{lccc}
\hline Variables & $\mathbf{b}(\mathbf{9 5} \% \mathbf{C l})$ & beta & $\boldsymbol{p}$ value \\
\hline $\begin{array}{l}\text { Formal employment } \\
\text { Yes }\end{array}$ & $-1.2(-1.9$ a -0.5$)$ & -0.320 & 0.002 \\
$\begin{array}{l}\text { Main caregiver } \\
\quad \text { Yes }\end{array}$ & $0.7(-0.1$ a 1.5$)$ & 0.171 & 0.083 \\
Feelings on family life & $-1.0(-1.5$ a -0.5$)$ & -0.412 & $<\mathbf{0 . 0 0 1}$ \\
$\quad$ How much does not providing care affects them & $0.3(-0.0$ a 0.7$)$ & 0.169 & 0.086 \\
$\begin{array}{l}\text { Financial support } \\
\quad \text { Yes }\end{array}$ & $0.9(0.1$ a 1.6$)$ & 0.218 & 0.027 \\
Help with ADLs & & & \\
$\quad$ Yes & $1.5(0.8$ a 2.2) & 0.398 & $<\mathbf{0 . 0 0 1}$ \\
\hline
\end{tabular}

Note: ADLs: Activities of Daily Living.

The factors that remained associated with overload after adjustment by the multivariate model were: formal employment, feelings on family life, financial support, and help with ADLs. Caregivers who helped the most with ADLs and provided financial support showed higher levels of overload, while those who had formal employment and presented happier feelings in relation to family life had lower levels of overload. The standardized regression coefficient value (beta) indicates that the two variables with greater impact on overload were, respectively, feelings on family life and help with ADLs. Regarding care behaviors, financial support and help with ADLs were statistically important factors for the overload of the caregiver child.

\section{DISCUSSION}

Similarly to the Canadian study with three groups of caregiver children (Canadians, Chinese, and Chinese residing in Canada), there was also a prevalence of married caregiver daughters who took care of older mothers ${ }^{(1,4)}$. Therefore, the prevalence of the female sex is in accordance with the result of other national and international studies ${ }^{(11-12,17-18,32-33)}$.

The high average age found was similar to other national studies ${ }^{(14,34-35)}$. However, it was higher than the results of the Canadian study in which researchers found an average age of $48.66 \pm 11.16$ years ${ }^{(2)}$. Different results were found regarding coliving. In this study, most of the children lived with their older parents, while the Canadian research found that only $34.6 \%$ of the children lived with their parents ${ }^{(3)}$. In other Brazilian studies conducted with family caregivers of older adults, most caregivers were daughters who lived with their parents $\mathrm{s}^{(8,11-12,35)}$.

In the Canadian study, considering the three cultural groups of caregiver children, the researchers found scores of Filial Expectation and Duty with overall averages of 20.85 and 25.12, respectively ${ }^{(2)}$. In this study, we found higher scores, however, we have to consider the cultural differences between the two countries. In Brazil, in addition to the moral question, care for older people is established in the Federal Constitution and specific laws, which establish the responsibility of the family, the State, and society. Legally, it is established that the care for older people should be primarily provided in their homes, to the detriment of institutionalization ${ }^{(36-38)}$.

It is possible to observe that care behaviors and the proportions of behaviors varied in the different groups of the Canadian study ${ }^{(2)}$. Brazilian children provide all five types of care in greater proportion (with the exception of help with ADLs), when compared to the groups of the Canadian study. As for the Canadian children of Chinese origin, the Canadians and Brazilians helped more with IADLs, while the Chinese of Hong Kong helped more with $\mathrm{ADLs}^{(2)}$. On the other hand, only the Brazilians stood out for keeping company and providing emotional support. It is possible that the behavior of Brazilians is also related to cultural aspects of greater appreciation of older parents and greater affective bonds and support between parents and 
children, results corroborated by a study conducted with caregiver daughters in the state of Minas Gerais ${ }^{(39)}$.

It was evidenced that the overload was greater in the "time-dependent" aspect and smaller on emotional life, i.e., the time that the caregiver children spends with their older parents influences their overload. In the study that originated the scale in Canada and that validated the scale in Brazil, the overload of caregivers was also greater in the "time-dependent overload" aspect (15.7 points) ${ }^{(30-31,40)}$.

In this study, the children did not feel so burdened regarding the emotional aspect. However, it is worth mentioning that in this study we did not assess the functional capacity of the older adults, which provides knowledge about their health conditions, an aspect that could influence in greater emotional overload. The lowest score on the "emotional overload" aspect has also been found in the development of the scale in Canada and in the validation studies of the scale in China(30-31,40).

In the original study ${ }^{(2)}$, the overload was greater in the social aspect. This aspect assesses the losses of caregivers concerning other people and the help they receive, or not, by other family members to take care of the older person. As already commented, while for the Brazilian children what overloads the most is taking care of the older person for a longer time, to the other three cultural groups of the baseline study, what overloaded the most was not having emotional support and having their time to social relations hindered. The research in China and the development of the scale in Canada identified a high score in the "overload to personal life" aspect (10.2 points $)^{(30,40)}$. This aspect assesses the feelings of the caregiver regarding the time spent to care for the older person that negatively influence their daily life and relationships with other people. Several studies indicate that activities aggregated to the daily routine of the caregiver, due to the needs of care to older people, predispose to overload, as this accumulation of functions reflects in their family relationships, difficulty to maintain or get a job, and having an affective relationship. This can generate a social isolation and changes in personal life, whereas, in most cases, caregivers find themselves alone to accomplish this task, and many point out that the aid promised by other family members does not always come ${ }^{(8,10,41-44)}$.

When analyzing the association between filial responsibility and overload, we observed that the children who had formal employment and presented happier feelings in relation to family life had lower levels of overload. Having a job and a good relationship with the family were some of the factors considered protective for the caregiver children. Such findings may be related to the fact that $37 \%$ of the children were not the main caregivers, moreover, $36 \%$ did not live with their parents. Therefore, in this study, the caregiver children who helped with ADLs and provided financial support showed higher levels of overload.

Help with ADLs is a task that requires greater dedication, in addition to being the most complex, and the demands of care increased according to the dependence of the older person. When this instrument was validated in China, associations were also found between caregiver overload and functional limitations of the older person. The "time-dependent overload" and "social life overload" aspects were positively associated with the degree of commitment in daily activities ${ }^{(40)}$. In addition, Chou states that, over time, the overhead can suffer changes due to the increase of weaknesses of the person cared for, the number of tasks involved, and the types of care needed $^{(45)}$.

In this study, financial support was an impacting factor on the overload of the children. In Brazil, it is possible that some children are financially dependent on their parents. According to Camarano and Kanso, situations in which the parents provide financial support and, on the other hand, the children help in the daily activities are common, or, in other circumstances, the older people seek help at their children homes, but also offer something in return ${ }^{(46)}$. As highlighted in other studies $^{(40,45)}$, the socioeconomic level is a factor that can influence caregivers negatively, generating a financial overload.

As for the variables that presented significant association with the overload, the socioeconomic factor stands out. It is believed that this may influence the decrease of caregivers' overload in this study. The fact that the subjects of this research are part of the Basic Health Unit located in the region with the highest education and income levels of the city, according to data from the last Demographic Census, draws attention $^{(47)}$. Thus, we can infer that presenting the highest income can contribute in reducing overload, as it allows family caregivers to hire professional caregivers to assist in the care activities. Nevertheless, the participants counted with the support of a home care team through the Home Care Program or the Family Health Strategy.

The lack of association between filial responsibility attitudes and overload may be related to the nature of the scales used to measure these attitudes. Filial Expectation assesses aspects related to attitudes such as living near the parents, having space for parents to live with them, being willing to take care of the parents, providing financial aid, and living near or visiting their older parents. While Filial Duty assesses helping the parents, following their advice, providing financial support, respecting them, pleasing them and making them happy, and keeping in touch. For the Canadian researchers ${ }^{(4)}$, the sense of filial responsibility, especially when it comes to a cultural standard, can be beneficial to the well-being of caring, i.e., not to overload the caregiver. For the researchers, the attitudes towards filial responsibility when caring for older parents can be considered as a moderator factor of the association between care and well-being, both positively and negatively, i.e., the children can experience situations that undermine their well-being, leading to a greater overhead, or are beneficial.

\section{Study limitations}

The causal direction of the results cannot be confirmed, thus being considered a limiting factor. In addition to the intentional sample, the study location and the participants were from a specific socioeconomic context, with better living conditions and access to health services, as well as counting with the organization of programmatic actions for the older 
population, which is a privileged context, considering the Brazilian scenario. Another limiting aspect was the lack of knowledge about the older people who were being cared for, such as income, functional capacity, and health situation.

\section{Contributions to the fields of nursing, public health or} public policy

Studies related to the overload of caregivers have already been the focus of several investigations, however, it is not known how this overload is related to care attitudes and behaviors of children with their older parents. In addition to contributing to the expansion of geriatric knowledge in the Brazilian context, the research adds to another international study, promoting the integration of scientific information and the comparison with the results of research from other countries. It also contributes to teaching and practice of nursing, as it discusses strategies for the assessment of caregiver children and of older people, in addition to development of proposals for intervention, in that it enables greater understanding about the responsibility of the children when caring for their parents and impacts arising from this care. Moreover, it can contribute to the development of health policies aimed at family caregivers in order to define support strategies to mitigate the impact of becoming a caregiver of a dependent older adult.

\section{CONCLUSION}

The caregiver children who helped the most with ADLs and provided financial support showed higher levels of overload.
Such findings have pointed to the need to support the caregiver, aiming at reducing the overload inherent to activities related to the provision of full-time care. Furthermore, the results are relevant to instigate in the health team, in society, and in the State, the necessity of implementation of public policies and actions of care with a view to providing formal support to caregivers.

Further research should be carried out in other contexts or different cultures to verify if responsibility attitudes are a protective factor for caregiver children. Another possibility would be to analyze the responsibility of children in caring for older parents in a longitudinal way, i.e., checking if changes in behaviors and attitudes and, therefore, increased levels of overload occur. In addition, further research is needed to explore whether filial responsibility attitudes are protective for this group.

\section{FUNDING}

This study received funding from the following institutions: Coordination for the Improvement of Higher Education Personnel (CAPES), National Council for Scientific and Technological Development $(\mathrm{CNPq})$, Fund for Incentive to Research and Events of the Clinics Hospital of Porto Alegre (HCPA/FIPE), and Research Support Foundation of Rio Grande do Sul (FAPERGS).

\section{ACKNOWLEDGEMENTS}

The Professor Doctor Neena Chapell, of the Centre on Aging, University of Victoria, Canada.

\section{REFERENCES}

1. Gans D, Silverstein M. Norms of Filial Responsibility for Aging Parents across Time and Generations. J Marriage Fam [Internet]. 2006 [cited 2015 Jan 21];68(4):961-76. Available from: http://dx.doi.org/10.1111/j.1741-3737.2006.00307

2. Chappell NL, Funk L. Filial Caregivers; diasporic chinese compared with homeland and hostland caregivers. J Cross Cult Gerontol [Internet]. 2011 [cited 2015 Jan 21];26(4):315-29. Available from: http://dx.doi.org/10.1007/s10823-011-9154-x

3. Chappell NL, Funk L. Filial responsibility: does it matter for care-giving behaviours? Ageing Soc [Internet]. 2012 [cited 2016 Mar 25];32(7):1128-46. Available from: http://dx.doi.org/10.1017/s0144686x11000821

4. Funk LM, Chappell NL, Liu G. Associations Between Filial Responsibility and Caregiver Well-Being: Are There Differences by Cultural Group?. Res Aging [Internet]. 2011 [cited 2016 Mar 25];35(1):78-95. Available from: http://dx.doi.org/10.1177/0164027511422450

5. Funk L. Comprehensive Special Area Exam: a critical literature review and synthesis on filial responsibility. Universidade de Victoria: Canadá. 2005

6. Chappell NL, McDonald L, Stones M. Social support and caregiving. In: Chappell NL, McDonald L, Stones M. Aging in contemporary Canada. 2ed. Toronto: Pearson Educational, 2008. p. 300-27.

7. Baptista BO, Beuter M, Girardon-Perlini NMO, Brondani CM, Budó MLD, Santos NO. A sobrecarga do familiar cuidador no âmbito domiciliar: uma revisão integrativa da literatura. Rev Gaúcha Enferm [Internet]. 2012 [cited 2017 Jan 25];33(1):14756. Available from: http://dx.doi.org/10.1590/S1983-14472012000100020

8. Pereira RA, Santos EBS, Fhon JRS, Marques S, Rodrigues RAP. Sobrecarga dos cuidadores de idosos com acidente vascular cerebral. Rev Esc Enferm USP [Internet]. 2013 [cited 2016 Sep 17];47(1):185-92. Available from: http://dx.doi.org/10.1590/ S0080-62342013000100023

9. Aires M, Fengler FL, Mocellin D, Morais EP, Rosset I, Paskulin LMGR. Adaptação transcultural do protocolo Filial Responsibility para uso no Brasil. Rev Bras Enferm. 2017. [in press]

10. Oliveira DC, D’Elboux MJ. Estudos nacionais sobre cuidadores familiares de idosos: revisão integrativa. Rev Bras Enferm [Internet]. 2012 [cited 2016 Out 21];65(5):829-38. Available from: http://dx.doi.org/10.1590/S0034-71672012000500017 
11. Seima MD, Lenardt MH, Caldas CP. Relação no cuidado entre o cuidador familiar e o idoso com Alzheimer. Rev Bras Enferm [Internet]. 2014 [cited 2016 Jan 17];67(2):233-40. Available from: http://dx.doi.org/10.5935/0034-7167.20140031

12. Loureiro LSN, Fernandes MGM, Nóbrega MML, Rodrigues RAP. Overburden on elderly's family caregivers: association with characteristics of the elderly and care demand. Rev Bras Enferm [Internet]. 2014 [cited 2016 Jul 21];67(2):227-32. Available from: http://dx.doi.org/10.5935/0034-7167.20140030

13. Costa TF, Costa KNFM, Martins KP, Fernandes, MGM, Brito SS. Sobrecarga de cuidadores familiares de idosos com acidente vascular encefálico. Esc Anna Nery [Internet]. 2015 [cited 2016 Mar 4];19(2):350-55. Available from: http://dx.doi. org/10.5935/1414-8145.20150048

14. Lino VTS, Rodrigues NCP, Camacho LAB, O'Dwyer G, Lima IS, Andrade MKN et al. Prevalência de sobrecarga e respectivos fatores associados em cuidadores de idosos dependentes, em uma região pobre do Rio de Janeiro, Brasil. Cad Saúde Pública [Internet]. 2016 [cited 2017 Jan 5];32(6):e00060115. Available from: http://dx.doi.org/10.1590/0102-311X00060115

15. Salgueiro $H$, Lopes M. A dinâmica da família que coabita e cuida de um idoso dependente. Rev Gaúcha Enferm [Internet]. 2010 [cited 2016 Jul 13];31(1):26-32. Available from: http://dx.doi.org/10.1590/S1983-14472010000100004

16. Zeng L, Zhu X, Meng X, Mao Y, Wu Q, Shi Y et al. Responsibility and burden from the perspective of seniors' family caregivers: a qualitative study in Shanghai, China. Int J [Internet].Clin Exp Med. 2014 [cited 2016 Jul 13];7(7):1818-28. Available from: https:// www.ncbi.nlm.nih.gov/pmc/articles/PMC4132150/pdf/ijcem0007-1818.pdf

17. Valle-Alonso MJ, Hernández-Lopez IE, Zúñiga-Vargas ML, Martínez-Aguilera P. Sobrecarga y burnout em cuidadores informales del adulto mayor. Enferm Univ [Internet]. 2015 [cited 2016 Jan 25];12(1):19-27. Available from: http://dx.doi.org/10.1016/j. reu.2015.05.004

18. Huang HL, Shyu YL, Chen MC, Huang CC, Kuo HC, Chen ST et al. Family caregivers' role implementation at different stages of dementia. Clin Interv Aging [Internet]. 2015 [cited 2016 Feb 17];10:135-46. Available from: http://dx.doi.org/10.2147/CIA.S60574

19. Thai JN, Barnhart CE, Cagle J, Smith AK. "It Just Consumes Your Life": quality of Life for Informal Caregivers of Diverse Older Adults With Late-Life Disability. Am J Hosp Palliat Care [Internet]. 2016 [cited 2015 Jan 17];33(7):644-50. Available from: http:// dx.doi.org/10.1177/1049909115583044

20. Anngela-Cole L, Hilton JM. The Role of Attitudes and Culture in Family Caregiving for Older Adults. Home Health Care Serv Q [Internet]. 2009 [cited 2017 Jan 27];28(2-3):59-83. Available from: http://dx.doi.org/10.1080/01621420903014790

21. Chappel N. Filial responsibility across cultures: a comparison of filial attitudes and behaviors in caregiving to older adults. (Research project) [Internet]- Centre on Ageing, University of Victoria, Victoria, 2008 [cited 2012 Mar 25]. Available from: http:// web.uvic.ca/ ${ }^{\sim}$ nlc/filial.htm

22. Secretaria Municipal da Saúde de Porto Alegre. Dados Demográficos de Porto Alegre - IBGE 2010. 2015 [cited 2015 Dec 18]. Available from: http://www2.portoalegre.rs.gov.br/sms/default.php?p_secao=918

23. Aires M, Weissheimer AM, Rosset I, de Oliveira FA, de Morais EP, Paskulin LM. Transcultural adaptation of the filial responsibility interview schedule for Brazil. Int Nurs Rev [Internet]. 2012 [cited 2015 Jan 21];59(2):266-73. Available from: http://dx.doi. org/10.1111/j.1466-7657.2011.00940.x

24. Seelbach WC, Sauer WJ. Filial responsibility expectations and morale among aged parents. Gerontologist [Internet]. 1977 [cited 2016 Jan 18];17(6):492-9. Available from: http://dx.doi.org/10.1093/geront/17.6.492

25. Gallois C, Giles H, Ota H, Pierson HD, Ng SH, Lim TS, Maher J et al. Intergenerational communication across the Pacific Rim: The impact of filial piety. Paper presented at the annual conference of the International Association of Cross-Cultural Psychology, Montreal (CA); 1961.

26. Katz S, Ford AB, Moskowitz RW, Jackson BA, Jaffe MW. Studies of Illness in the Aged. The Index of ADL: A Standardized Measure of Biological and Psychosocial Function. JAMA [Internet]. 1963 [cited 2016 Feb 13];185(12):914-9. Available from: http://dx.doi. org/10.1001/jama.1963.03060120024016

27. Lawton MP, Brody E. Assessment of older people: self-maintaining and instrumental activities of daily living. Gerontologist [Internet]. 1969 [cited 2016 Feb 13];9(3):179-86. Available from: http://dx.doi.org/10.1093/geront/9.3_Part_1.179

28. Freitas EV, Miranda RD, Nery MR. Parâmetros clínicos do envelhecimento e avaliação geriátrica global. In: Freitas EV, Py L, Neri AL, Cançado FAX, Gorzoni ML, Rocha SM (org). Tratado de geriatria e gerontologia. Rio de Janeiro: Guanabara Koogan; 2002. p. 609-617.

29. Duarte $\mathrm{YAO}$, Andrade CL, Lebrão ML. O index de Katz na avaliação da funcionalidade dos idosos. Rev. Esc Enferm USP [Internet]. 2007 [cited 2016 Feb 21];41(2):317-25. Available from: http://dx.doi.org/10.1590/S0080-62342007000200021

30. Novak M, Guest C. Application of a Multidimensional Caregiver Burden Inventory. Gerontologist [Internet]. 1989 [cited 2015 Jan 18];29(6):798-803. Available from: http://dx.doi.org/10.1093/geront/29.6.798

31. Valer DB, Aires M, Fengler FL, Paskulin LMG. Adaptation and validation of the Caregiver Burden Inventory for use with caregivers of elderly individuals. Rev Latino-Am Enferm [Internet]. 2015 [cited 2015 Jan 17];23(1):130-8. Available from: http://dx.doi. org/10.1590/0104-1169.3357.2534

32. Del-Pino-Casado R, Frías-Osuna A, Palomino-Moral PA. Subjective burden and cultural motives for caregiving in informal caregivers of older people. J Nurs Scholarsh [Internet]. 2011[cited 2016 Feb 3];43(3):282-91. Available from: http://dx.doi. 
$\operatorname{org} / 10.1111 / \mathrm{j} .1547-5069.2011 .01407 . x$

33. Del Corso AR, Lanz M. Felt obligation and the family life cycle: A study on intergenerational relationships. Int J Psychol [Internet]. 2013 [cited 2015 Feb 3];48(6):1196-200. Available from: http://dx.doi.org/10.1080/00207594.2012.725131

34. Nardi EFR, Sawada NO, Santos JLF. Associação entre a incapacidade funcional do idoso e a sobrecarga do cuidador familiar. Rev Latino-Am Enferm [Internet]. 2013 [cited 2016 Aug 11];21(5):1096-103. Available from: http://dx.doi.org/10.1590/ S0104-11692013000500012

35. Fuhrmann AC, Bierhals CCBK, dos Santos NO, Paskulin LM. Association between the functional capacity of dependent elderly people and the burden of family caregivers. Rev Gaúcha Enferm [Internet]. 2015 [cited 2017 Jan 9];36(1):14-20. Available from: http://dx.doi.org/10.1590/1983-1447.2015.01.49163

36. Brasil. Constituição da República Federativa do Brasil. Brasília (DF): Senado Federal; 1988.

37. Brasil. Senado Federal. Estatuto do Idoso. Brasília (DF): Senado Federal; 2003.

38. Brasil. Ministério da Saúde. Portaria n² 2.528, de 19 de outubro de 2006. Aprova a Política Nacional de Saúde da Pessoa Idosa. Brasília (DF): Ministério da Saúde; 2006.

39. Jesus MCP, Merighi MAB, Caldeira S, Oliveira DM, Souto RQ, Pinto MA. Cuidar da mãe idosa no contexto domiciliar: perspectiva de filhas. Texto Contexto Enferm [Internet]. 2013 [cited 2016 Feb 17];22(4):1081-88. Available from: http://dx.doi.org/10.1590/ S0104-07072013000400026

40. Chou KR, Chyun LJ, Chu H. The reliability and validity of the Chinese version of the caregiver burden inventory. Nurs Res [Internet] 2002 [cited 2017 Jan 4];51(5):324-31. Available from: http://dx.doi.org/10.1097/00006199-200209000-00009

41. Silva LCP. Cuidado de Enfermagem à Pessoa idosa no Domicílio. In: Menezes MR, Amaral JB, Silva VA, Alves MB. Enfermagem Gerontológica: um olhar diferenciado no cuidado biopsicossocial e cultural. São Paulo: Martinari, 2016.

42. Oliveira APP, Caldana RHL. As repercussões do cuidado na vida do cuidador familiar do idoso com demência de Alzheimer. Saude Soc [Internet]. 2012 [cited 2017 Jan 4];21(3):675-85. Available from: http://dx.doi.org/10.1590/S0104-12902012000300013

43. Fernandes MGM, Garcia TR. Determinantes da tensão do cuidador familiar de idosos dependentes. Rev Bras Enferm [Internet]. 2009 [cited 2017 Jan 20];62(3):393-9. Avalilable from: http://dx.doi.org/10.1590/S0034-71672009000100009

44. Rocha MPF, Vieira MA, Sena RR. Desvelando o cotidiano dos cuidadores informais de idosos. Rev Bras Enferm [Internet]. 2008 [cited 2017 Jan 20];61(6):801-8. Available from: http://dx.doi.org/10.1590/S0034-71672008000600002

45. Chou KR. Caregiver burden: a concept analysis. J Pediatr Nurs [Internet]. 2000 [cited 2017 Jan 4];15(6):398-407. Available from: http://dx.doi.org/10.1053/jpdn.2000.16709

46. Camarano AA, Kanso S. Como as famílias brasileiras estão lidando com idosos que demandam cuidados e quais as perspectivas futuras? A visão mostrada pelas PNADs. In: Camarano AA (org.). Cuidados de longa duração para a população idosa: um novo risco social a ser assumido? Rio de Janeiro: IPEA, 2010 [cited 2015 Jan 4]. p. 93-123. Available from: http://www.ipea.gov.br/ agencia/images/stories/PDFs/livros/livro_cuidados.pdf

47. Instituto Brasileiro de Geografia e Estatística. Censo Demográfico 2010. Rio de Janeiro, 2010 [cited 2016 Dec 15]. Available from: http://www.ibge.gov.br/censo2010/resultados_do_censo2010.php 